\title{
Personality, Learning Entrepreneurship, and Attitude as Predictors of Economic Students' Entrepreneur Behavior
}

\author{
Susanti \\ Universitas Negeri Surabaya \\ Surabaya - Indonesia \\ susanti@unesa.ac.id
}

\author{
Han Tantri Hardini \\ Universitas Negeri Surabaya \\ Surabaya- Indonesia \\ hantantrihardini@gmail.com
}

\begin{abstract}
This study aims to examine the influence between: (1). Personality on entrepreneurship behavior, (2). Entrepreneurship learning on entrepreneurship behavior, (3). Attitudes to entrepreneurship behavior, and (4.) Simultaneous influence between personality, entrepreneurship learning and entrepreneurial attitude toward entrepreneurship behavior. The population in this study is all students of the Faculty of Economics, State University of Surabaya who have taken entrepreneurship courses, and the sample is all students who have entrepreneurship. The total sample is 50 students. Data collection was conducted in April 2018. From the research result, it was found that there was influence of personality, entrepreneurship learning and entrepreneurship attitude toward entrepreneurship behavior of student of Faculty of Economics, Universitas Negeri Surabaya- Indonesia.
\end{abstract}

Keywords - personality; entrepeneurship learning; attitudes; entrepreneurship behavior

\section{INTRODUCTION}

The challenge faced in the development of a country is to address the problem of unemployment. Central Bureau of Statistics in Indonesia is Badan Pusat Statistik (BPS) revealed, in 2017 there has been an increase in the number of unemployed in Indonesia 7,04 million people in August 2017 from August 2016 of 7,03 million people. Head of BPS Kecuk Suhariyanto said the increase in unemployment is due to the increase in the number of labor force in Indonesia. By 2018, the Ministry of Research, Technology and Higher Education has recorded about $8.8 \%$ of the total 7 million unemployed in Indonesia is undergraduate. These undergraduate graduates are unlikely to become unemployed if they have an entrepreneurial spirit. The curriculum at the University should provide entrepreneur courses as a solution. Entrepreneurship courses have also been incorporated in the university curriculum in Indonesia, for example the University curriculum in East Java namely Universitas Negeri Surabaya.

The high level of unemployment is dominated by young people aged 15-24. This is evidenced by the existence of statistical data that exist in all regions in Indonesia. Based on BPS Surabaya in 2017, a total of 5,780 scholars did not get a job. Unemployment rate of undergraduate graduates reaches $6.46 \%$ of total 89,000 workforce. The number of unemployed graduates rose compared to 2015, which reached 5,310 workers. Based on statistical data in Surabaya it clearly gives an ironic picture, where the high level of education does not guarantee someone to get a job.

Various efforts have been made to improve the quality of graduates from universities in order to find employment so that the unemployment rate may decrease. Universities in Indonesia provide entrepreneurship-based curriculum either as compulsory or elective courses. The government and the private sector are also working to increase the number of entrepreneurs from the younger generation by organizing competitions and providing entrepreneurial grants through many programs, such as Entrepreneurship Student Creativity Program, Entrepreneurial Student Program, Entrepreneurial Student Self and others. This is an opportunity for students to compete to obtain capital, which later will be used as their initial capital in running a business.

The younger generation are expected to have entrepreneurial behavior to bridge them into unemployment in the future. There are some previous research results related to entrepreneurial behavior. Some research results indicate the influence of one's personality on entrepreneurial behavior. The results of Arasteh, et al in Islamic Azad University of Sari (IAUSI) of university in Iran stated that students have a positive personality in entrepreneurship [1] The clarity of the minds of female students is better than male students, but in achieving the dreams and expectations of higher male students. The results of Nitu and Feder's study at the Faculty of Economics and Business Administration from West University of Timişoara resulted in data that personality characteristics are antecedents of behavioral characteristics depending on the situational constraints that allow their expressions [2]. In addition to personality factors, based on previous studies there is an influence between entrepreneurial learning on entrepreneurial behavior. The results of research in 
Indonesia show that entrepreneurship education influences the behavior of entrepreneurial students. The results of research abroad, according to Turker and Selcuks in Daim, et al explain that the rules in education / learning are the determining factors that trigger the entrepreneurial spirit of students [3] The results of Nitu and Feder's research explain that if entrepreneurship education and learning increases, then the awareness of students in entrepreneurship will increase and provide benefits for increasing the number of young entrepreneurs [2]. While research in Canada is the result of research Menzies and Tatroff in Daim, et al explained that education helps increase the number of female entrepreneurs [3]. The results of other studies show that there is an influence between entrepreneurial attitudes toward entrepreneurial behavior. Result of research of Gedik, et al explain there is influence between entrepreneurship attitude toward entrepreneurship behavior [4].

Based on the above, then the formulation of the problem in this study are as follows:

1. Is there any influence between personalities to entrepreneurship behavior of student of Faculty of Economics of Universitas Negeri Surabaya?

2. Is there any influence between entrepreneurship learning on the entrepreneurship behavior of students of the Faculty of Economics, Universitas Negeri Surabaya?

3. Is there any influence of entrepreneurship attitude toward entrepreneurship behavior of student of Faculty of Economics of Universitas Negeri Surabaya?

4. Is there a simultaneous influence between personality factors, entrepreneurship learning and attitudes toward entrepreneurship behavior of students of the Faculty of Economics, Universitas Negeri Surabaya?

\section{LITERATURE REVIEW}

\section{A. Entrepreneurship}

Sethi says about Entrepreneurship is a process of establishing a business organization, which provides goods and services, creates jobs, and contributes to the national income and the overall economic development [5]. Entrepreneurship is a process that happens in various environments during where changes happen in the economic system through innovation of those who react to economic opportunities and this causes establishment of individual and social value. Entrepreneurs do three main activities: (1) Business (2) Innovation in product, process, manufacture and market products and services (3) Employment, growth and national development [6].

\section{- Personality}

Personality, according to Larsen \& Buss is a collection of trait and psychological mechanisms within an organized and relatively enduring individual and affects interaction and adaptation, intrapsychic, physical and social environment [7]. A person's personality affects the way individuals react, think, feel, interact, and adapt to others, including in aggressive behavior. The results of the research indicate that personality and psychological features of employees are effective in their entrepreneurship skills in working place [8].

\section{- Entrepreneurship Education}

Entrepreneurship education has been defined by a lot of researchers in the literature. Henry defines it as giving students the ability to recognize situations that can create interesting business creations. [9] Further it also provides them with the necessary skills required for successful business start-ups. Martinez et al. defines entrepreneurial education is more about entrepreneurship in the broader sense, entrepreneurial training is specifically provided for firm creation [10]. Oosterlinc, et al Entrepreneurship education, opportunity perception, selfefficacy and gender have a positive significant influence on entrepreneurship behavior taking into account country fixed effects [11].

- Attitude

The GEM distinguishes three components of entrepreneurship: attitude, activity, and aspirations [12]. According to Robbins, attitude is an evaluative statement either profitable or unbecoming about objects, people, and events [13]. Based on the GEM report, entrepreneurial attitudes consist of how entrepreneurs are perceived in society, whether there are opportunities, etcetera.

\section{- Entrepeneur Behavior}

According Skinner, behavior is a response or a person's reaction to stimulus or stimuli from the outside. While J.B Say explains that entrepreneurs are entrepreneurs who can manage various resources that are owned economically \& increase low productivity becomes high. An entrepreneur is someone who creates new business by taking risks and uncertainties in order to achieve profit and growth by identifying significant opportunities and combining the resources needed so that those resources can be capitalized Based on the understanding of behavior and entrepreneurship, it can be explained that entrepreneurial behavior is a reaction as well as a positive response conducted by individuals to create a new form of business both goods and services through ways that are independent, creative, innovative, hard work even at risk in order to gain profits so that needs her life is fulfilled at the moment

\section{METHODS}

This research is included in the type of quantitative research. Independent / independent variables in this study consisted of three variables, namely personality, entrepreneurial learning, and attitude. While the dependent variable is entrepreneurship behavior. The population in this study is all students in the Department of Economic Education Faculty of Economics force 2014/2015 who have taken entrepreneurship courses as many as 303 students. While the sample in this study are students who entrepreneurship. Based on the existing data it turns out there are 50 students who do entrepreneurship so that the 
total is used as sample research. Data collection techniques in this study using questionnaires to be distributed to respondents. Before the dissemination, the questionnaire should be tested for its validity and reliability. Questionnaires are valid and reliable later will be the actual research. Data analysis technique used to test the influence of variables is multiple linear regression. Partial test between variables is done by using $\mathrm{R}$ test and $\mathrm{t}$ test. While the test simultaneously used $\mathrm{F}$ test.

\section{RESULT AND DISCUSSION}

\section{A. Result}

1. Characteristics of entrepreneurial respondents in the Faculty of Economics, Universitas Negeri Surabaya : The results of descriptive analysis indicate the type of business undertaken by students majoring in economic education Faculty of Economics, State University of Surabaya can be shown in table 1 below:

TABLE I. TYPE OF BUSINESS UNDERTAKEN BY STUDENTS FACULTY OF ECONOMICS, UNIVERSITAS NEGERI SURABAYA

\begin{tabular}{|c|l|c|}
\hline No & \multicolumn{1}{|c|}{ Type of Business } & Total \\
\hline 1. & Food, Drinks, Cakes and others & 14 \\
\hline 2. & Shoes, Slippers, Bags and others & 6 \\
\hline 3. & Gadgets, Handphone, Pulses, HP and others & 3 \\
\hline 4. & Fashion & 9 \\
\hline 5. & Beauty products & 6 \\
\hline 6. & Women's knick knacks & 2 \\
\hline 7. & Handycraft (souvenir, and others) & 3 \\
\hline 8. & Education (learning guidance, and others) & 7 \\
\hline & Total Respondent & 50 \\
\hline
\end{tabular}

Based on table 1 it can be concluded that the type of business that most of the students are food products, beverages and cakes. The next effort is fashion, the field of education in the form of private course as well as the business of buying and selling beauty products. Enterprises with the lowest respondent are computers, gadgets, Hand phone; handicraft and women's knick knacks (hena painting services, fake nails and other).

2. Test Results coefficient of t test, and F test

Below is table 2 which shows the result of t test as follows:

\section{TABLE II. COEFFICIENTS}

\begin{tabular}{|l|r|r|c|r|r|}
\hline \multirow{2}{*}{ Model } & \multicolumn{2}{|c|}{$\begin{array}{c}\text { Unstandardized } \\
\text { Coefficients }\end{array}$} & $\begin{array}{l}\text { Standardized } \\
\text { Coefficients }\end{array}$ & & \multirow{2}{*}{ Sig. } \\
\cline { 2 - 4 } & \multicolumn{1}{c|}{ B } & Std. Error & Beta & \multicolumn{1}{c|}{ t } & \multicolumn{1}{c|}{ Sig. } \\
\hline (Constant) &,- 039 & 2,989 & &,- 013 &, 990 \\
\hline Personality & 1,352 &, 073 &, 921 & 18,409 &, 000 \\
\hline $\begin{array}{l}\text { Entrepeneurship } \\
\text { Learning }\end{array}$ &, 264 &, 108 &, 120 & 2,435 &, 019 \\
\hline Attitudes &, 184 &, 070 &, 125 & 2,631 &, 012 \\
\hline
\end{tabular}

a. Dependent Variable: Entrepeneurship Behavior

Table 2 is used to test the hypothesis of variability among variables. Based on the data can be explained as follows:
Ha 1: There is a personality influence on entrepreneurship behavior of students of Faculty of Economics, Universitas Negeri Surabaya

Based on the above coefficient table, the t-count value for the personality variable is $18.409>1.67866$, so $\mathrm{Ha} 1$ is accepted. Then it can be concluded that there is influence between personality variables on entrepreneurship behavior of students of Faculty of Economics, Universitas Negeri Surabaya

Ha 2 : There is influence of student entrepreneurship learning on entrepreneurship behavior of students of Faculty of Economics, Universitas Negeri Surabaya

Based on the above coefficient table, the value of $\mathrm{t}$-count for the variable of 2.435> 1.67866, so that Ha2 is accepted. Then it can be concluded that there is influence between entrepreneurship learning variables on entrepreneurship behavior of students of Faculty of Economics, Universitas Negeri Surabaya.

Ha 3: There is influence of entrepreneurship attitude toward entrepreneurship behavior of student of Faculty of Economics, State University of Surabaya.

Based on the above coefficient table, the value of t-count for the entrepeneurship attitudes variable of 2.631> 1.67866, so that $\mathrm{Ha} 3$ is accepted. Then it can be concluded that there is influence between entrepreneurship attitudes variable to entrepreneurship behavior of students of Faculty of Economics, Universitas Negeri Surabaya.

The results of the F test can be shown in the following ANOVA table:

\section{TABLE III. ANOVA}

\begin{tabular}{|l|r|r|r|r|r|}
\hline \multicolumn{1}{|c|}{ Model } & Sum of Squares & df & $\begin{array}{c}\text { Mean } \\
\text { Square }\end{array}$ & F & Sig. \\
\hline Regression & 1488,985 & 3 & 496,328 & 139,627 &, $000^{\mathrm{b}}$ \\
Residual & 163,515 & 46 & 3,555 & & \\
Total & 1652,500 & 49 & & & \\
\hline
\end{tabular}

a. Dependent Variable: Entrepeneurship Behavior

b. Predictors: (Constant), entrepeneurship Attitudes, Entrepeneurship

Learning, Personality

Ha 4: There is a simultaneous influence between personality, entrepreneurship learning, and entrepreneurship attitude toward entrepreneurship behavior of students of Faculty of Economics, Universitas Negeri Surabaya.

In table 4 above the value of $F$ arithmetic $>F$ table is 139.627> 2.81 and significance level $0.00<0.05$ then Ha4 accepted. So it can be concluded there is a simultaneous influence between personality, entrepreneurship learning, and entrepreneurship attitudes toward entrepreneurship behavior of students of the Faculty of Economics, Universitas Negeri Surabaya.

\section{B. Discussion}

1. There is influence between the personalities of entrepreneurship behavior of students of Faculty of Economics, Universitas Negeri Surabaya: According to the theory that entrepreneurs are people who dare to open 
independent productive activities. Attitudes and Behavior are strongly influenced by the nature and character possessed by a person. A good, progressive and positive oriented nature and character are the traits and traits needed by an entrepreneur in order for the entrepreneur to progress / succeed. Nature and character are a reflection of one's personality. There are four types of entrepreneurial personalities, personal achiever, super salesperson, real manager, and expert idea generation. The type of entrepreneurial personality can determine the line of business that will lead to success.

The important factors that led to the start of a business by a person by Bygrave in Alma are: (1) personal, concerning aspects of one's personality, (2) sociological, concerning problems with family and so forth, (3) environment, someone with its environment. Furthermore, Bygrave in Alma states that the most encouraging person to enter entrepreneurial career involves two things:

Personal factors [14]. An entrepreneur is someone who has desire of achievement is very high compared with people who are not entrepreneur, (2) environmental factors - in addition to the personal factors that exist within the selfentrepreneurial self, there is influence of external factors on the formation of entrepreneurial character.

Empirical results also indicate the existence of support influence between personalities to entrepreneurship behavior. The results of this study in accordance with the results of research Arasteh, et al in Islamic Azad University of Sari (IAUSI) in Iran states that students have a positive personality in entrepreneurship that affect behavior in entrepreneurship [1]. The results of Nitu and Feder resulted in the conclusion that personality characteristics are antecedents of behavioral characteristics depending on the situational constraints that allow their expressions [2]. The results of research in Indonesia that is Mochlasin and Krisnawati also resulted in the conclusion of the existence of influence between personality variables on entrepreneurship behavior [15].

2. There is influence between entrepreneurship learning on entrepreneurship behavior of students of Faculty of Economics, Universitas Negeri Surabaya. : Jones and English described entrepreneurial education as the process of providing individuals with the ability to recognize commercial opportunities and the insight, self-esteem, knowledge and skills to act on them [16]

According to Suryana that "Entrepreneurship is not only born but also made" means entrepreneurship is not only innate talent since born or field experience affairs, but can also be learned and taught [17]. Therefore, to become a successful entrepreneur, talent alone is not enough, but also must have knowledge of all aspects of the business that will be dilekinya in entrepreneurship education process.

The results of empirical studies also indicate the existence of influence between entrepreneurship learning variables on entrepreneurship behavior. The results of research in Indonesia that is Mochlasin and Krisnawati resulted in the conclusion that there is influence between entrepreneurship educations on the behavior of entrepreneurial students [15]. The results of Turker and Selcuks research in Daim, et al that the rules in education are the determining factors that trigger student entrepreneurship spirit [3]. The results of Nitu and Feder that if the learning of entrepreneurship is improved, it is guaranteed awareness of students in entrepreneurship will increase as well [2]. The results of Menzies and Tatroff in Daim, et al explain that education helps increase the number of women entrepreneurs [3].

3. There is influence between attitudes toward entrepreneurship behavior of students of Faculty of Economics, Universitas Negeri Surabaya: Campbel (1950) in Notoadmodjo's book suggests that attitude is "A syndrome of response consistency with regard to social objects"[18] Behavior is strongly influenced by the nature or character, attitudes and perceptions that are owned by someone. Properties or attitudes, attitudes and perceptions are good, oriented to progress and positive is the nature or character, attitudes and perceptions needed by an entrepreneur so that entrepreneurs can progress / success. While Gibson et al. defines attitude as a positive or negative feeling or mental state that is always prepared, studied, and organized through experience, which gives a special impact on a person's response to people, objects or circumstances [19]. Attitudes toward behavior are conceptualized as "the extent to which a person has a favorable or unfavorable evaluation or judgment of questionable behavior", in this case an entrepreneur [20]

The result of empirical study shows the existence of influence between entrepreneurship attitude variable to entrepreneurship behavior. Mulyadi conducted a study of the relationship between attitudes and behavior resulted in the conclusion that there is influence between attitudes toward behavior [21]. Sari's research results also shows the existence of both directly or indirectly influence between attitudes toward entrepreneurship behavior of students at the University of Education Ganesha [22]. The results of Gedik also yield the same conclusions as this research [4].

4. There is a simultaneous influence between personality, entrepreneurship learning and attitudes toward entrepreneurship behavior of students of the Faculty of Economics, Universitas Negeri Surabaya: The results showed that simultaneously variable personality, entrepreneurship learning, and entrepreneurial attitude influence on student entrepreneurship behavior. So it can be concluded that the relationship that occurs between variables in the sample research can apply to the population in this study.

\section{CONCLUSION}

Based on the results of research and discussion, it can be concluded that entrepreneurial behavior of students of the Economics Faculty of Universitas Negeri Surabaya is influenced by personality factors, attitudes, and entrepreneurial learning that they have gained when studying on campus. 


\section{REFERENCES}

[1] H. Arasteh, T. Enayati, F. Zameni, and A. Khademloo, "Entrepreneurial Personality Characteristics of University Students: A Case Study," Procedia - Soc. Behav. Sci., vol. 46, pp. 5736-5740, 2012.

[2] R. D. Niţu-Antonie and E. S. Feder, "The role of economic academic education on entrepreneurial behaviour," Amfiteatru Econ., vol. 17, no. 38, pp. 261-276, 2015.

[3] T. Daim, M. Dabic, and E. Bayraktaroglu, "Students' entrepreneurial behavior: international and gender differences," J. Innov. Entrep., vol. 5, no. 19, pp. 1-22, 2016.

[4] Ş. Gedik, M. Miman, and M. S. Kesici, "Characteristics and Attitudes of Entrepreneurs Towards Entrepreneurship," Procedia Soc. Behav. Sci., vol. 195, no. 3 July 2015, pp. 1087-1096, 2015.

[5] J. Sethi, "Entrepreneur and Entrepreneurship"

[6] K. A. Akbari, Development of Entrepreneurship. Tehran: University Jihad Organization, 2007.

[7] R. J. Larsen, Personality Psychology : Domains of Knowledge about Human Nature Fourth Edition. New York : McGraw-Hill, 2010.

[8] Malakshah and A. Karimpoor, "How do personality features and skills affect entrepreneurship," International Review., 2017

[9] C. Henry, F. Hill, and C. Leitch, "Entrepreneurship education and training: can entrepreneurship be taught? Part I," Education and Training., vol. 47 no.2, pp 98-111, 2005.

[10] A.C. Martinez, J. Levie, D. J. Kelley, R. J. Saemundsson, T. Schot, Global Entrepreneurship Monitor Special Report. A global perspective on entrepreneurship and training. Massachusets : Babson College, 2010

[11] J. Oosterlinck, O. Leiding, and D. Vercruysee, The influence of entrepreneurship education on entrepreneurial behavior. Belgium: Universiteit Gent, 2016

[12] N. S. Bosma, J. Levie, "Global Enterpreneurship Monitor 2009 Excecutive Report"

[13] S. P. Robbins, Perilaku Organisasi : Konsep, Kontroversi, Aplikasi. Jakarta: PT. Prenhallindo, 2008

[14] B. Alma, "Kewirausahaan". Bandung: Alfabeta, 2003.

[15] Mochlasin and Krisnawati, "Faktor-Faktor yang Mempengaruhi Perilaku Kewirausahaan Enterpreneur Muslim Salatiga”, Jurnal Ekonomi dan Perbankan Syariah., vol. 7, no.2, 2016.

[16] C. Jones and J. English, "A contemporary approach to entrepreneurship education," Education and Training., vol. 6, no.8/9, pp. 416-423, 2004.

[17] Suryana, Kewirausahaan Pedoman Praktis : Kiat dan Proses Menuju Sukses. Jakarta: Salemba Empat, 2009.

[18] Notoatmodjo and Soekidjo, Pendidikan dan Perilaku Kesehatan. Jakarta: Rineka Cipta, 2003.
[19] J. L. Gibson, J. M. Ivancevich, J. H. Donnelly, Organisasi : Perilaku, Struktur, Proses, Jakarta: Binarupa Aksara, 2008

[20] I. Ajzen, "Perceived Behavioral Control, Self Efficacy, Locus of Control, and The Theory of Planned Behavior," Journal of Applied Social Psychology., vol. 32, no. 4, pp. 665-683, 2002.

[21] H. Mulyadi, "Pengaruh Pendidikan Kewirausahaan Terhadap Sikap Kewirausahaan Serta Dampaknya Pada Perilaku Kewirausahaan Mahasiswa, Lembaga Penelitian dan Pengabdian kepada Masyarakat Universitas Pendidikan Indonesia.”

[22] N. M. A. T. Sari, "Pengaruh pelatihan, sikap, intensi, dan modal terhadap perilaku berwirausaha pada peserta program mahasiswa wirausaha," Ekuitas - Jurnal Pendidikan Ekonomi., vol. 1, no. 1, 2013. 